\title{
Nutrient Demand Affects Ruminal Digestion Responses to a Change in Dietary Forage Concentration ${ }^{1}$
}

\author{
J. A. Voelker Linton and M. S. Allen ${ }^{2}$ \\ Department of Animal Science, Michigan State University, East Lansing 48824
}

\begin{abstract}
Previous research in our laboratory has indicated that the physical filling effects of high-forage diets become increasingly dominant in determining feed intake and milk production as nutrient demand increases. This effect was tested further by using 14 ruminally and duodenally cannulated Holstein cows in a crossover design experiment with a 14-d preliminary period and two 15-d experimental periods. During the preliminary period, 3.5\% fat-corrected milk yield was 15 to $60 \mathrm{~kg} / \mathrm{d}$ (mean $=40 \mathrm{~kg} / \mathrm{d})$, and preliminary voluntary dry matter intake (pVDMI) was 20.6 to $30.5 \mathrm{~kg} / \mathrm{d}$ (mean $=25.0 \mathrm{~kg} /$ d). Treatments were a low-forage diet (LF), containing $20 \%$ (dry matter basis) forage neutral detergent fiber (NDF), and a high-forage diet (HF), containing $27 \%$ forage NDF. The ability of linear and quadratic factors of $\mathrm{pVDMI}$ to predict the difference in responses of individual cows to treatments $\left(\mathrm{Y}_{\mathrm{LF}}-\mathrm{Y}_{\mathrm{HF}}\right)$ was tested by ANOVA, with treatment sequence as a covariate. In contrast to results of previous research, differences in dry matter intake and fat-corrected milk yield responses to LF and HF did not depend on pVDMI. This might be because of the combined physical fill and metabolic satiety effects of LF, especially in cows with the greatest $\mathrm{pVDMI}$. Digestion or passage of NDF might have been inhibited on LF among high-pVDMI cows. As pVDMI increased, NDF turnover time increased more on LF than on HF. Among high-pVDMI cows, the NDF turnover time was unexpectedly greater on LF than on HF. With increasing $\mathrm{pVDMI}$, the digestion rate of potentially digestible NDF decreased at a similar rate on both diets. Passage rates of potentially digestible NDF and indigestible NDF were not related to pVDMI, regardless of treatment. Greater starch fermentation (resulting from greater starch intake) for LF as pVDMI increased likely inhibited NDF digestion
\end{abstract}

\footnotetext{
Received February 8, 2007.

Accepted June 21, 2007.

${ }^{1}$ This project was supported by National Research Initiative Competitive Grant no. 2006-35206-16708 from the USDA Cooperative State Research, Education, and Extension Service.

${ }^{2}$ Corresponding author: allenm@msu.edu
}

through $\mathrm{pH}$-dependent and $\mathrm{pH}$-independent effects. Inhibition of NDF digestion might cause LF and HF to have similar effects on dry matter intake, depending on the nutrient demand of individual cows.

Key words: nutrient demand, dietary forage fiber concentration, digestion kinetics

\section{INTRODUCTION}

Dietary forage NDF concentration affects feeding and digestion in dairy cows through both physical and chemical mechanisms. Physical controls include gut distension (Lehman, 1941) and limitations on the time spent eating (Allen, 2000). Mechanisms through which diet affects the physical control of feed intake include retention time of digesta fractions (Campling et al., 1961), potential digestibility of the fiber (Oba and Allen, 1999b), diet particle size and rate of particle size reduction (Poppi et al., 1980), particle specific gravity (Balch and Kelly, 1951), and diet effects on the frequency and duration of reticulorumen contractions (Okine and Mathison, 1991; Dado and Allen, 1995). Altered fermentation acid production in the rumen resulting from changes in dietary forage NDF concentration may also affect intake and digestion responses to the diet (Sheperd and Combs, 1998). Excess production of fermentations acids with low-forage-fiber diets can depress feed intake (Allen, 2000) and result in lower ruminal $\mathrm{pH}$, which can decrease fiber digestibility (Hoover, 1986).

However, energy balance influences both feed intake responses to diet characteristics and the extent to which physical or metabolic factors limit voluntary DMI (VDMI; Mertens, 1994; Allen, 1996). The effects on feed intake of dietary characteristics (such as dietary forage NDF concentration) that influence the ruminal passage rate of digesta will depend on the extent to which physical filling effects limit feed intake in an individual animal. Testing only overall treatment mean differences may mask important differences in intake, digestion, and production responses that would suggest different management decisions for animals with different nutrient demands (Allen, 2000). We developed and successfully used an experimental model to evaluate effects of indices of nutrient demand, such as preliminary milk 
Table 1. Status of 14 cows during the final $4 \mathrm{~d}$ of the preliminary period, when cows were fed a common diet

\begin{tabular}{lccc}
\hline Variable & Mean & Range & SD \\
\hline Parity & 2.9 & $2.0-4.0$ & 0.7 \\
BW, kg & 597 & $502-725$ & 55 \\
BCS & 2.6 & $1.7-4.0$ & 0.7 \\
DIM & 178 & $67-388$ & 120 \\
Milk yield, kg/d & 38.7 & $16.1-59.1$ & 12.3 \\
DMI, kg/d & 25.0 & $20.6-30.5$ & 2.7 \\
\hline
\end{tabular}

yield, on animal responses to dietary treatments (Oba and Allen, 1999a; Burato et al., 2001; Voelker et al., 2002; Bradford and Allen, 2004; Harvatine and Allen, 2005). In a previous experiment (Voelker et al., 2002), we used this model with intact and ruminally cannulated cows to test our hypothesis that preliminary VDMI (pVDMI) affects individual responses of the VDMI and digesta passage rate to diets containing high and low concentrations of forage NDF. In that experiment, DMI became increasingly greater for a low-forage diet compared with a high-forage diet as pVDMI increased, and NDF digestion kinetic responses to treatments also depended on pVDMI (Voelker et al., 2002). The current experiment was conducted by using ruminally and duodenally cannulated cows with a wide range of pVDMI to investigate the mechanisms underlying the responses to changes in dietary forage-fiber concentration observed in the previous experiment. We hypothesized that passage rates of digesta fractions would become increasingly greater for a low-forage diet (LF) compared with a high-forage $\operatorname{diet}(\mathbf{H F})$ as pVDMI increased.

\section{MATERIALS AND METHODS}

\section{Cows and Treatments}

Experimental procedures were approved by the Institutional Animal Care and Use Committee at Michigan State University. Fourteen multiparous Holstein cows from the Michigan State University Dairy Cattle Teaching and Research Center were assigned randomly to treatment sequence in a crossover design experiment with a 14-d preliminary period and two 15-d experimental periods. These 14 cows were $178 \pm 120$ (mean \pm SD) DIM at the beginning of the preliminary period (Table 1) and were selected deliberately to provide a wide distribution of 3.5\% FCM yield (FCMY) and DMI (Figure 1). During the 14-d preliminary period, milk yield ranged from 16.1 to $59.1 \mathrm{~kg} / \mathrm{d}($ mean $=38.7 \mathrm{~kg} / \mathrm{d})$ and pVDMI ranged from 10.6 to $30.5 \mathrm{~kg} / \mathrm{d}$ (mean $=25.0 \mathrm{~kg} /$ d). Cows were cannulated ruminally and duodenally prior to calving. Surgery was performed at the Department of Large Animal Clinical Science, College of Veter-
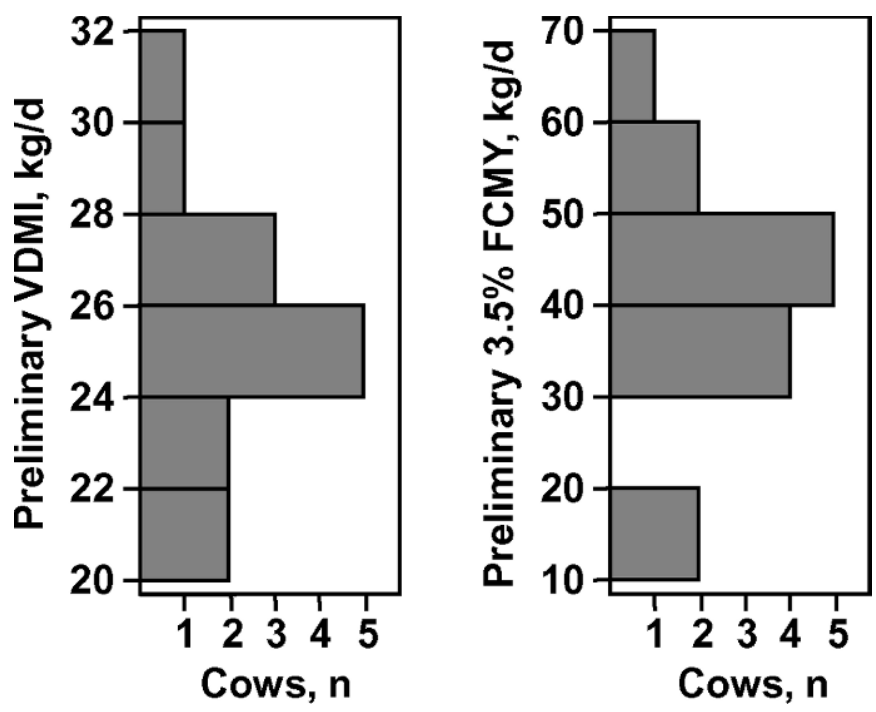

Figure 1. Distribution of voluntary DMI (VDMI) and 3.5\% fatcorrected milk yield (FCMY) of 14 cows during the final $4 \mathrm{~d}$ of the preliminary period, when cows were fed a common diet.

inary Medicine, Michigan State University. Cows were housed in tie stalls and fed once daily (1100 h) at $110 \%$ of expected intake.

Treatments (Table 2) were LF and HF fed as totally mixed rations. Diet LF was formulated to contain $20 \%$ of DM as forage NDF and contained $24 \%$ total dietary $\mathrm{NDF}$, and diet $\mathrm{HF}$ was formulated to contain $27 \%$ forage NDF and contained $31 \%$ total dietary NDF (Table 2). Forages were corn silage and alfalfa silage, and diets were formulated so that the relative contributions of the 2 forages to total forage NDF were equal in both diets. Forage-to-concentrate ratios (\% of DM) were 45:55 for LF and 61:39 for HF. Diets also contained dry ground corn, soybean meal, SoyPlus (an expellerprocessed soybean meal obtained from West Central Soy, Ralston, IA), and a vitamin-mineral premix; urea and soybean meal were used to achieve similar estimated CP and RUP fractions in the 2 diets. No nonforage fiber sources were used so that measurements of intake and digestion of NDF fractions would reflect primarily forage NDF. Forage NDF contributed the majority of total NDF in both diets $(82.2 \%$ for $\mathrm{LF}$ and $87.8 \%$ for HF; data not shown). Because the nonforage ingredients had higher DM concentrations than did the forages, the HF had a lower dietary DM concentration than did the LF (Table 2). Diets were formulated for $18 \%$ dietary $\mathrm{CP}$, but the actual dietary CP concentrations were 16.2 and $16.6 \%$ (Table 2). The diet fed during the preliminary period was formulated (with the same ingredients) to contain $24 \%$ forage NDF. 
Table 2. Ingredient and nutrient composition of treatment diets, a low-forage diet (LF) and a high-forage diet (HF)

\begin{tabular}{|c|c|c|}
\hline Variable & $\mathrm{LF}$ & $\mathrm{HF}$ \\
\hline \multicolumn{3}{|l|}{ Ingredient } \\
\hline Corn silage $^{1}$ & 29.7 & 40.5 \\
\hline Alfalfa silage $^{2}$ & 15.1 & 20.9 \\
\hline Dry ground corn & 33.9 & 16.1 \\
\hline Soybean meal (48\% CP) & 11.0 & 9.1 \\
\hline Vitamin-mineral mix $^{3}$ & 3.2 & 4.3 \\
\hline SoyPlus $^{4}$ & 5.9 & 9.1 \\
\hline Urea & 0.2 & - \\
\hline \multicolumn{3}{|l|}{ Nutrient } \\
\hline $\mathrm{DM}, \%$ as fed & 47.0 & 39.6 \\
\hline $\mathrm{OM}$ & 93.0 & 92.1 \\
\hline $\mathrm{NDF}$ & 24.4 & 30.7 \\
\hline Forage NDF & 19.9 & 27.3 \\
\hline Indigestible NDF & 13.2 & 15.1 \\
\hline Potentially digestible $\mathrm{NDF}^{5}$ & 11.2 & 15.6 \\
\hline Starch & 32.8 & 22.5 \\
\hline $\mathrm{CP}$ & 16.2 & 16.6 \\
\hline Rumen-undegraded $\mathrm{CP}^{6}$ & 7.2 & 7.3 \\
\hline
\end{tabular}

${ }^{1}$ Corn silage contained $46.4 \% \mathrm{NDF}, 16.9 \%$ indigestible NDF, $18.6 \%$ starch, and $8.1 \% \mathrm{CP} ; 30$-h in vitro NDF digestibility was $47.5 \%$.

${ }^{2}$ Alfalfa silage contained $40.6 \% \mathrm{NDF}, 26.4 \%$ indigestible NDF, $3.5 \%$ starch, and $18.3 \% \mathrm{CP} ; 30$-h in vitro NDF digestibility was $32.6 \%$.

${ }^{3}$ Vitamin-mineral mix contained (DM basis) $10.1 \%$ dicalcium phosphate, $4.1 \%$ trace-mineral premix, $5.7 \%$ sodium bicarbonate, $1.2 \%$ magnesium oxide, $124.2 \mathrm{kIU} / \mathrm{kg}$ of vitamin A, $40.3 \mathrm{kIU} / \mathrm{kg}$ of vitamin $\mathrm{D}, 671.6 \mathrm{kIU} / \mathrm{kg}$ of vitamin $\mathrm{E}$, and $60.1 \%$ ground corn grain as a carrier.

${ }^{4}$ West Central Soy (Ralston, IA). Nutrient composition: 86\% DM, $7 \%$ ash, $16 \% \mathrm{NDF}, 5 \%$ starch, and $51 \% \mathrm{CP}$.

${ }^{5}(1$ - indigestible NDF).

${ }^{6}$ Estimated by using values from NRC (2001).

\section{Sample and Data Collection}

The amounts of feed offered and orts were weighed daily for each cow. Samples of all dietary ingredients $(0.5 \mathrm{~kg})$ and orts from each cow $(12.5 \%$ of orts) were collected daily on d 11 to 13 and combined into one sample per period. Cows were milked twice daily in a milking parlor (0300 and $1500 \mathrm{~h}$ ); milk yield was measured, and milk was sampled, at each milking on d 11 to 13. Rumen-empty BW was measured after evacuation of ruminal digesta on d 14 of the preliminary period and on d 15 of each experimental period. Body condition score was determined on the same days by 3 trained investigators blinded to treatments (Wildman et al., 1982; 5-point scale, where $1=$ thin and $5=$ fat).

Duodenal samples for digestion measurements $(700$ $\mathrm{mL}$ ) and for particle-size analysis $(700 \mathrm{~mL})$, rumen fluid samples for microbial isolation $(350 \mathrm{~mL})$, and rumen fluid samples for $\mathrm{pH}(100 \mathrm{~mL})$ were collected every $9 \mathrm{~h}$ from $\mathrm{d} 11$ to 13 . Thus, 8 samples were obtained for each cow in each period, representing every $3 \mathrm{~h}$ of a 24 -h period to account for diurnal variation. Rumen fluid for microbial isolation was collected from the reticulum, near the reticular-omasal orifice, and strained through a layer of nylon mesh ( 1 mm pore size). Rumen fluid for $\mathrm{pH}$ was obtained by combining digesta from 5 different sites in the rumen and straining it through a layer of nylon mesh; fluid $\mathrm{pH}$ was recorded immediately. Samples were stored immediately at $-20^{\circ} \mathrm{C}$.

Ruminal contents were evacuated manually through the ruminal cannula at $1600 \mathrm{~h}$ ( $5 \mathrm{~h}$ after feeding) on $\mathrm{d}$ 14 and at $0700 \mathrm{~h} \mathrm{(} 4 \mathrm{~h}$ before feeding) on $\mathrm{d} 15$ of each period. Total ruminal content mass and volume were determined. During evacuation, $10 \%$ aliquots of digesta were separated to allow accurate sampling. Aliquots were squeezed through a nylon screen $(\sim 1 \mathrm{~mm}$ pore size) to separate them into primarily solid and liquid phases. Both phases were weighed and sampled (two $350-\mathrm{mL}$ samples of each phase) for determination of nutrient pool size and particle size analysis. Samples were stored at $-20^{\circ} \mathrm{C}$.

\section{Sample and Statistical Analyses}

Dietary ingredients and orts were dried in a $55^{\circ} \mathrm{C}$ forced-air oven for $72 \mathrm{~h}$ and analyzed for DM concentration. All samples were ground with a Wiley mill (1-mm screen; Authur H. Thomas, Philadelphia, PA). One set of frozen duodenal samples for each cow period $(n=8)$ was chopped finely by using a commercial food processor (84142 Food Cutter, Hobart Manufacturing Co., Troy, $\mathrm{OH}$ ) and subsampled in the frozen state to obtain representative samples. These duodenal subsamples and one set of 350-mL ruminal solid and liquid samples for each rumen-emptying time were lyophilized (TriPhilizer MP, FTS Systems, Stone Ridge, NY) and ground as described above. Dried ruminal solid and liquid samples were recombined according to the original ratio of solid and liquid DM. Samples were analyzed for ash, NDF, indigestible NDF (iNDF), CP, and starch. Ash concentration was determined after $5 \mathrm{~h}$ of oxidation at $500^{\circ} \mathrm{C}$ in a muffle furnace. Concentrations of NDF were determined according to Van Soest et al. (1991, method A). Indigestible NDF was estimated as NDF residue after a 120-h in vitro fermentation (Goering and Van Soest, 1970). Rumen fluid for the in vitro incubations was collected from a nonpregnant dry cow fed only alfalfa hay. The fraction of potentially digestible NDF (pdNDF) was calculated by the difference (1.00 iNDF). Crude protein was analyzed according to Hach et al. (1987). Starch was measured by an enzymatic method (Karkalas, 1985) after samples were gelatinized with sodium hydroxide. Glucose concentration was measured by using a glucose oxidase method (Glucose kit \#510; Sigma Chemical Co., St. Louis, MO), and absorbance was determined with a microplate reader (SpectraMax 190, Molecular Devices Corp., Sunnyvale, 
CA). Concentrations of all nutrients except DM were expressed as percentages of DM, as determined by drying at $105^{\circ} \mathrm{C}$ in a forced-air oven for more than $8 \mathrm{~h}$.

Milk samples were analyzed for fat, true protein, MUN, and lactose with midinfrared spectroscopy (AOAC, 1990) by Michigan DHIA (East Lansing), and 3.5\% FCMY was calculated (Tyrrell and Reid, 1965).

Indigestible NDF was used as an internal marker to estimate nutrient digestibility in the rumen (Cochran et al., 1986), fractional rates of passage for iNDF, pdNDF, and starch, and fractional rates of digestion for pdNDF and starch. Nutrient intake was calculated by using the composition of feed offered and orts. Ruminal pool sizes ( $\mathrm{kg}$ ) of OM, NDF, iNDF, pdNDF, and starch were determined by multiplying the concentration of each component by the ruminal digesta DM mass $(\mathrm{kg})$. Turnover time in the rumen, passage rate from the rumen, and ruminal digestion rate of each component $(\% / \mathrm{h})$ were calculated as reported by Voelker and Allen (2003).

Rates of particle size reduction in, and particle passage from, the rumen also were determined by using iNDF as a marker (Figure 2). Triplicate 20 -g feed and orts samples were sieved. Thawed subsamples of ruminal solid and liquid phases (the second set from each of 2 rumen evacuations per period) were recombined into duplicate 60-g samples based on the original (wet) ratio of solid and liquid phases. The second set of whole duodenal samples was thawed and combined (8 per cow period), then separated into liquid and solid phases and stored frozen. The 2 phases were thawed and recombined in duplicate 200-g samples based on the original (wet) ratio of solid and liquid phases. Feed, orts, rumen, and duodenal samples were individually wet-sieved sequentially through $4.75 \mathrm{~mm}, 2.36 \mathrm{~mm}$, and $38 \mu \mathrm{m}$ screens (W. S. Tyler Inc., Gastonia, NC). Particles retained on each screen were removed and dried at $55^{\circ} \mathrm{C}$ for $48 \mathrm{~h}$, then weighed. Materials retained on each screen from replicate sievings were combined (keeping after-feeding and before-feeding rumen-empty samples separate). Because DM in duodenal digesta retained on the $4.75-\mathrm{mm}$ screen was $<5 \%$ of total DM on the screens, $2.36 \mathrm{~mm}$ was selected as the threshold for passage. Residue $\geq 2.36 \mathrm{~mm}$, including residue on 4.75 - and 2.36$\mathrm{mm}$ screens, averaged $13.4 \%$ of total DM. Therefore, particles retained on the 2.36- and $4.75-\mathrm{mm}$ screens were combined and the resulting fractions were designated as $\geq 2.36 \mathrm{~mm}$ (less likely to escape the rumen) and $<2.36 \mathrm{~mm}$ (more likely to escape the rumen). These 2 fractions were ground ( $1 \mathrm{~mm}$, Wiley mill) and analyzed for DM, iNDF, and NDF concentrations. The proportions of iNDF in the total intake and rumen pool of $\mathrm{NDF}$ were calculated as kilograms of iNDF/(kilograms of iNDF + kilograms of pdNDF); proportions of pdNDF were calculated similarly. Indigestible NDF was used to calculate the rate of particle size reduction in the rumen ( $\geq 2.36$ to $<2.36$ ), because 1 ) kinetics must be calculated for a homogeneous pool, and 2) pdNDF can leave the pool by digestion as well as by particle-size reduction and passage, but iNDF can leave the pool only by breakdown or by passage. Passage rates of iNDF in large $(\geq 2.36 \mathrm{~mm})$ and small $(<2.36 \mathrm{~mm})$ particles, the rate of flux of iNDF from the $\geq 2.36 \mathrm{~mm}$ pool to the $<2.36 \mathrm{~mm}$ pool (reduction rate), and the relative size threshold for escape from the rumen were calculated as follows:

Passage rate $\left(\mathrm{k}_{\mathrm{p}}\right)$ :

$$
\begin{aligned}
& \text { iNDF } k_{\mathrm{p} \geq 2.36}= \\
& \mathrm{iNDF}_{\text {Duod } \geq 2.36}(\mathrm{~kg} / \mathrm{d}) / \mathrm{iNDF}_{\text {RumenPool } \geq 2.36}(\mathrm{~kg}) \text {, and } \\
& \text { iNDF } k_{\mathrm{p}<2.36}= \\
& \mathrm{iNDF}_{\text {Duod<2.36 }}(\mathrm{kg} / \mathrm{d}) / \mathrm{iNDF}_{\text {RumenPool<2.36 }}(\mathrm{kg}) \text {, }
\end{aligned}
$$

where iNDF $k_{p}$ is the passage rate of iNDF in particles $\geq 2.36$ or $<2.36 \mathrm{~mm}, \mathrm{iNDF}_{\text {Duod }}$ is the duodenal flow of iNDF in particles $\geq 2.36$ or $<2.36 \mathrm{~mm}$, and NDDF $_{\text {RumenPool }}$ is the rumen pool of iNDF in particles $\geq 2.36$ or $<2.36$ $\mathrm{mm}$.

Reduction rate $\left(\mathrm{k}_{\mathrm{r}}\right)$ from $\geq 2.36$ to $<2.36 \mathrm{~mm}$ :

$$
\begin{gathered}
\mathrm{iNDF} \mathrm{k}_{\mathrm{r} 2.36}=\left[\mathrm{iNDF}_{\mathrm{In} \geq 2.36}(\mathrm{~kg} / \mathrm{d})\right. \\
\left.-\mathrm{iNDF}_{\text {Duod } 22.36}(\mathrm{~kg} / \mathrm{d})\right] / \mathrm{iNDF}_{\text {RumenPool } \geq 2.36}(\mathrm{~kg}),
\end{gathered}
$$

where iNDF $k_{\mathrm{r} 2.36}$ is the rate of transfer of iNDF from the pool of particles $\geq 2.36 \mathrm{~mm}$ to the pool of particles $<2.36 \mathrm{~mm}, \mathrm{iNDF}_{\mathrm{In} \geq 2.36}$ is the intake of iNDF in particles $\geq 2.36 \mathrm{~mm}$, $\mathrm{iNDF}_{\mathrm{Duod} \geq 2.36}$ is the duodenal flux of iNDF in particles $\geq 2.36 \mathrm{~mm}$, and $\mathrm{iNDF}_{\text {RumenPool } \geq 2.36}$ is the rumen pool of iNDF in particles $\geq 2.36 \mathrm{~mm}$.

Relative size threshold:

$$
\mathrm{iNDF}_{\text {Duod } 22.36}(\mathrm{~kg} / \mathrm{d}) / \mathrm{iNDF}_{\text {DuodTotal }}(\mathrm{kg} / \mathrm{d}) \text {, }
$$

where $i \mathrm{NDF}_{\text {Duod } \geq 2.36}$ is the duodenal flux of iNDF in particles $\geq 2.36 \mathrm{~mm}$, and $\mathrm{iNDF}_{\text {DuodTotal }}$ is the duodenal flux of iNDF in all particles. Passage rates and relative size threshold were also calculated for pdNDF.

To determine differences between treatments, all data were analyzed by using the fit model procedure of JMP (Version 5.1.2, SAS Institute, Cary, NC) according to the following model:

$$
\mathrm{Y}_{\mathrm{ijk}}=\mu+\mathrm{C}_{\mathrm{i}}+\mathrm{P}_{\mathrm{j}}+\mathrm{T}_{\mathrm{k}}+\mathrm{PT}_{\mathrm{jk}}+\mathrm{e}_{\mathrm{ijk}},
$$

where $\mu$ is the overall mean, $C_{i}$ is the random effect of cow ( $i=1$ to 14$), P_{j}$ is the fixed effect of period ( $j=1$ to 


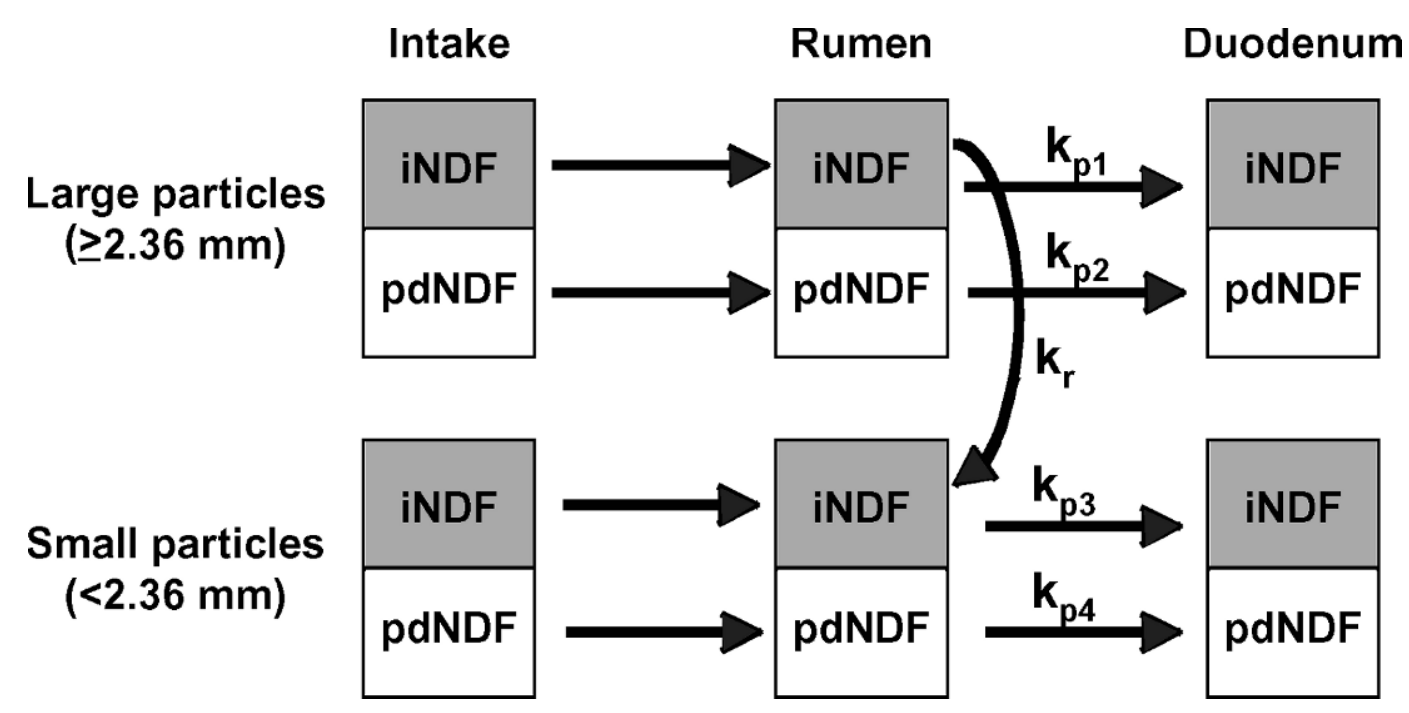

Figure 2. Model of ruminal particle size reduction and passage. Reduction of particle size during eating is included in the rate of particle size reduction $\left(\mathrm{k}_{\mathrm{r}}\right)$. Passage rates $\left(\mathrm{k}_{\mathrm{pi}}\right)$ are calculated for indigestible NDF (iNDF) and potentially digestible NDF (pdNDF); $\mathrm{k}_{\mathrm{r}}$ is calculated for iNDF only.

2 ), $\mathrm{T}_{\mathrm{k}}$ is the fixed effect of treatment ( $\mathrm{k}=1$ to 2$), \mathrm{PT}_{\mathrm{jk}}$ is the interaction of period and treatment, and $\mathrm{e}_{\mathrm{ijk}}$ is the residual, which is assumed to be normally distributed. The period $\times$ treatment interaction effect was removed when its $P$-value was greater than 0.30 .

To correlate the response to treatment with pVDMI and thus test the primary hypothesis, the response $(\mathrm{Y})$ for each response variable was calculated for each cow as follows:

$$
\mathrm{Y}=\mathrm{y}_{\mathrm{LF}}-\mathrm{y}_{\mathrm{HF}},
$$

where $\mathrm{y}_{\mathrm{LF}}$ is the response for the LF diet and $\mathrm{y}_{\mathrm{HF}}$ is the response for the HF diet.

Preliminary VDMI was calculated, for each cow, as the mean of DMI values on $\mathrm{d} 11$ to 14 of the 14-d preliminary period. Relationships between the response to treatment and pVDMI were analyzed according to the following model:

$$
\mathrm{Y}_{\mathrm{i}}=\mu+\mathrm{S}_{\mathrm{i}}+\mathrm{V}+\mathrm{V}^{2}+\mathrm{e}_{\mathrm{i}}
$$

where $Y_{i}$ is $y_{L F}-y_{H F}, \mu$ is the overall mean, $S_{i}$ is the effect of sequence ( $\mathrm{i}=1$ to 2 ), $\mathrm{V}$ is $\mathrm{pVDMI}, \mathrm{V}^{2}$ is $\mathrm{pVDMI}{ }^{2}$, and $e_{i}$ is the residual, which is assumed to be normally distributed.

Animals in sequence 1 received LF in period 1 and $\mathrm{HF}$ in period 2; animals in sequence 2 received $\mathrm{HF}$ in period 1 and LF in period 2. Significance was declared at or below $P=0.05$, and tendencies were declared at or below $P=0.10$.

\section{RESULTS AND DISCUSSION}

\section{Mean Responses to Dietary Forage NDF Concentration}

This experiment was designed to test the effect of pVDMI on the response to treatment. However, the reporting and discussion of select treatment effects are merited. Consistent with the majority of previously reported experiments comparing low-forage and high-forage diets (Allen, 2000), mean DMI was greater for cows fed LF compared with HF (Table 3), despite the wide range in pVDMI. Intake of both NDF and forage NDF was greater for HF than for $\mathrm{LF}(P<0.001)$, but intake of iNDF was similar between treatments $(P \geq 0.85)$. Rumen pools of DM, NDF, and iNDF were greater for $\mathrm{HF}$, even though cows consumed less DM when fed HF. The intake and ruminal pool responses suggest that physical fill was more limiting to intake for HF than for $\mathrm{LF}$ for most cows.

Effects of treatment on the ruminal starch digestion rate could not be determined because of a period $\times$ treatment interaction. However, the ruminal pdNDF digestion rate was greater for $\mathrm{HF}$ than for LF (Table 3; $P=$ $0.001)$. It is likely that the greater starch intake and fermentation observed for LF compared with HF (Table $3 ; P<0.0001)$ contributed to the reduced pdNDF digestion rate for LF by directly inhibiting NDF digestion, in addition to acting through the slight reduction of ruminal $\mathrm{pH}$ observed for LF compared with HF (Table 3; $P<0.0001$; Grant and Mertens, 1992).

The rate of reduction of feed particles from $\geq 2.36$ to $<2.36 \mathrm{~mm}$ (measured by using iNDF as a marker) was 
Table 3. Least squares means of responses in feed intake, digestion, and production of 14 Holstein cows to low-forage (LF) and high-forage (HF) diets

\begin{tabular}{|c|c|c|c|c|c|}
\hline \multirow[b]{2}{*}{ Variable $^{1}$} & \multicolumn{4}{|c|}{ Treatment LSM } & \multirow{2}{*}{$\begin{array}{c}\text { Trt } \times \\
\text { Per, } P\end{array}$} \\
\hline & LF & $\mathrm{HF}$ & $\mathrm{SED}^{2}$ & $P$ & \\
\hline \multicolumn{6}{|l|}{ Intake, $\mathrm{kg} / \mathrm{d}$} \\
\hline $\mathrm{DM}$ & 27.8 & 24.7 & 0.5 & $<0.0001$ & $\mathrm{NS}^{3}$ \\
\hline $\mathrm{NDF}$ & 6.8 & 7.5 & 0.1 & $<0.001$ & NS \\
\hline iNDF & 3.8 & 3.8 & 0.1 & 0.86 & NS \\
\hline Forage $\mathrm{NDF}^{4}$ & 5.6 & 6.7 & 0.1 & $<0.0001$ & NS \\
\hline Starch & 9.2 & 5.5 & 0.2 & $<0.0001$ & NS \\
\hline \multicolumn{6}{|l|}{ Ruminal pool, kg } \\
\hline $\mathrm{DM}$ & 10.8 & 11.1 & 0.2 & 0.09 & NS \\
\hline $\mathrm{NDF}$ & 5.7 & 6.2 & 0.1 & $<0.01$ & NS \\
\hline iNDF & 3.1 & 3.5 & 0.1 & $<0.0001$ & NS \\
\hline pdNDF digestion rate, ${ }^{5} \% / \mathrm{h}$ & 3.31 & 4.74 & 0.33 & 0.001 & NS \\
\hline Starch digestion rate, $\% / \mathrm{h}$ & 27.4 & 28.0 & 2.9 & $\mathrm{NE}^{6}$ & $<0.01$ \\
\hline \multicolumn{6}{|l|}{ NDF digested in the rumen } \\
\hline $\mathrm{kg} / \mathrm{d}$ & 2.0 & 3.0 & 0.2 & $<0.0001$ & NS \\
\hline$\%$ of NDF intake & 29.3 & 40.1 & 2.3 & $<0.001$ & NS \\
\hline Starch digested in the rumen, $\mathrm{kg} / \mathrm{d}$ & 4.8 & 3.2 & 0.2 & $<0.0001$ & NS \\
\hline Mean pH & 5.86 & 6.00 & 0.02 & $<0.0001$ & NS \\
\hline \multicolumn{6}{|l|}{ Ruminal passage rate, $\% / \mathrm{h}$} \\
\hline iNDF & 5.11 & 4.63 & 0.22 & $\mathrm{NE}$ & 0.06 \\
\hline $\operatorname{pdNDF}^{6}$ & 1.57 & 1.04 & 0.26 & 0.06 & NS \\
\hline Starch & 25.8 & 19.1 & 4.4 & $\mathrm{NE}$ & 0.08 \\
\hline Rumen turnover time of NDF, $\mathrm{h}$ & 20.9 & 19.0 & 1.1 & $\mathrm{NE}$ & 0.16 \\
\hline \multicolumn{6}{|l|}{ Yield, kg/d } \\
\hline Milk & 39.6 & 36.1 & 0.6 & 0.0001 & NS \\
\hline $3.5 \% \mathrm{FCM}$ & 41.5 & 39.1 & 0.7 & $<0.01$ & NS \\
\hline Fat & 1.51 & 1.46 & 0.03 & 0.13 & NS \\
\hline Milk fat concentration, $\%$ & 3.79 & 3.93 & 0.06 & 0.04 & NS \\
\hline BW change, $\mathrm{kg} / 15 \mathrm{~d}$ & 8.2 & -2.0 & 2.5 & $<0.01$ & NS \\
\hline BCS change, $\mathrm{kg} / 15 \mathrm{~d}$ & 0.02 & -0.03 & 0.07 & 0.47 & NS \\
\hline
\end{tabular}

${ }^{1} \mathrm{iNDF}=$ indigestible NDF; pdNDF = potentially digestible NDF.

${ }^{2} \mathrm{SE}$ of the difference.

${ }^{3}$ Not significant $(P \geq 0.30)$; Trt $\times$ Per removed from model.

${ }^{4}$ Estimated as DMI $\times$ dietary forage NDF concentration.

${ }^{5}$ pdNDF (\% DM), calculated as NDF - iNDF.

${ }^{6}$ Not estimable because of a significant Trt $\times$ Per interaction.

much greater $(P<0.0001)$ on $\mathrm{HF}(6.92 \% / \mathrm{h})$ than on $\mathrm{LF}$ $(3.81 \% / \mathrm{h}$; Table 4$)$. This could be the result of greater fragility of large (forage) particles on HF because of the faster rate of pdNDF digestion. It also could be the result of more chews, or more effective ruminating chews, per kilogram of ruminal NDF. Chewing behavior was not measured in this experiment. In a similar experiment (Voelker et al., 2002), time spent ruminating and total chewing time were greater for the high-forage diet than for the low-forage diet, but time chewing per kilogram of intake of NDF and forage NDF were greater for the low-forage diet. Wilson and Kennedy (1996) suggested that physical mastication of forage particles, rather than increased fragility caused by digestion, was the most important mechanism for particle size reduction. However, digestion does increase the rate of particle size reduction by increasing fragility (Chai et al., 1984).

Intake of iNDF in particles $<2.36 \mathrm{~mm}$ was greater for LF $(P<0.0001)$, and intake of iNDF in particles $\geq 2.36 \mathrm{~mm}$ was greater for $\mathrm{HF}(P<0.0001$; Table 4$)$. Intake of pdNDF responded similarly (Table 4). The ruminal pool of iNDF in particles $<2.36 \mathrm{~mm}$ was greater for HF than for LF $(P<0.0001)$, but the pool of iNDF in particles $\geq 2.36 \mathrm{~mm}$ was similar between treatments $(P \geq 0.50)$. Ruminal pools of pdNDF in large and small particles were similar across treatments $(P>0.25)$. For both treatments, the NDF in ruminal particles $<2.36$ mm contained a larger proportion of iNDF than did the $\mathrm{NDF}$ in ruminal particles $\geq 2.36 \mathrm{~mm}$ (Table 4). Because a greater lignin concentration results in greater fragility (McLeod and Minson, 1988), particles with greater iNDF concentration might break down to smaller particles more quickly. Therefore, small particles should contain greater concentrations of iNDF than should larger particles, as was observed.

In addition to the observed differences caused by treatments, comparisons of proportions of NDF within treatment but across location (intake vs. ruminal pool) might support previous observations that large parti- 
Table 4. Least squares means of particle size kinetic responses of 14 Holstein cows to low-forage (LF) and high-forage (HF) diets

\begin{tabular}{|c|c|c|c|c|}
\hline \multirow[b]{2}{*}{ Variable $^{1}$} & \multicolumn{2}{|c|}{ Treatment LSM } & \multirow[b]{2}{*}{$\mathrm{SED}^{2}$} & \multirow[b]{2}{*}{$P$} \\
\hline & $\mathrm{LF}$ & $\mathrm{HF}$ & & \\
\hline \multicolumn{5}{|l|}{ Intake } \\
\hline iNDF $<2.36 \mathrm{~mm}, \mathrm{~kg} / \mathrm{d}$ & 2.35 & 1.87 & 0.04 & $<0.0001$ \\
\hline $\mathrm{iNDF} \geq 2.36 \mathrm{~mm}, \mathrm{~kg} / \mathrm{d}$ & 1.46 & 1.96 & 0.04 & $<0.0001$ \\
\hline $\mathrm{pdNDF}^{3}<2.36 \mathrm{~mm}, \mathrm{~kg} / \mathrm{d}$ & 1.96 & 1.51 & 0.03 & $<0.0001$ \\
\hline $\mathrm{pdNDF} \geq 2.36 \mathrm{~mm}, \mathrm{~kg} / \mathrm{d}$ & 1.85 & 2.32 & 0.04 & $<0.0001$ \\
\hline iNDF $<2.36 \mathrm{~mm}, \%$ of NDF & 54.5 & 55.4 & 0.2 & $<0.01$ \\
\hline iNDF $\geq 2.36 \mathrm{~mm}, \%$ of NDF & 44.1 & 45.7 & 0.2 & $<0.0001$ \\
\hline pdNDF $<2.36 \mathrm{~mm}, \%$ of NDF & 45.5 & 44.6 & 0.2 & $<0.01$ \\
\hline $\mathrm{pdNDF} \geq 2.36 \mathrm{~mm}, \%$ of $\mathrm{NDF}$ & 55.9 & 54.3 & 0.2 & $<0.0001$ \\
\hline \multicolumn{5}{|l|}{ Rumen pool } \\
\hline iNDF $<2.36 \mathrm{~mm}, \mathrm{~kg}$ & 2.17 & 2.52 & 0.05 & $<0.0001$ \\
\hline iNDF $\geq 2.36$ mm, kg & 0.92 & 0.96 & 0.05 & 0.53 \\
\hline $\mathrm{pdNDF}<2.36 \mathrm{~mm}, \mathrm{~kg}$ & 1.43 & 1.50 & 0.06 & 0.25 \\
\hline $\mathrm{pdNDF} \geq 2.36 \mathrm{~mm}, \mathrm{~kg}$ & 1.16 & 1.21 & 0.07 & 0.48 \\
\hline iNDF $<2.36 \mathrm{~mm}, \%$ of NDF & 60.9 & 62.8 & 0.9 & 0.05 \\
\hline iNDF $\geq 2.36 \mathrm{~mm}, \%$ of NDF & 44.6 & 44.8 & 2.6 & 0.92 \\
\hline pdNDF $<2.36 \mathrm{~mm}, \%$ of NDF & 39.1 & 37.1 & 0.9 & 0.05 \\
\hline $\mathrm{pdNDF} \geq 2.36 \mathrm{~mm}, \%$ of NDF & 55.4 & 55.2 & 1.8 & 0.92 \\
\hline \multicolumn{5}{|l|}{ Passage rate, $\% / \mathrm{h}$} \\
\hline $\mathrm{iNDF}<2.36 \mathrm{~mm}$ & 6.09 & 5.67 & 0.17 & 0.03 \\
\hline iNDF $\geq 2.36 \mathrm{~mm}$ & 2.85 & 2.10 & 0.26 & 0.01 \\
\hline $\mathrm{pdNDF}<2.36 \mathrm{~mm}$ & 2.34 & 1.70 & 0.31 & 0.06 \\
\hline $\mathrm{pdNDF} \geq 2.36 \mathrm{~mm}$ & 0.64 & 0.59 & 0.17 & 0.78 \\
\hline Rate of reduction (iNDF pool $\geq 2.36$ to iNDF pool $<2.36 \mathrm{~mm}$ ), $\% / \mathrm{h}$ & 3.81 & 6.92 & 0.47 & $<0.0001$ \\
\hline \multicolumn{5}{|l|}{ Duodenal flux $\geq 2.36 /$ total duodenal flux } \\
\hline iNDF & 0.15 & 0.13 & 0.009 & 0.03 \\
\hline pdNDF & 0.16 & 0.21 & 0.02 & $<0.05$ \\
\hline
\end{tabular}

${ }^{1} \mathrm{iNDF}=$ indigestible NDF: pdNDF = potentially digestible NDF.

${ }^{2} \mathrm{SE}$ of the difference.

${ }^{3}$ pdNDF (\% of DM), calculated as NDF - iNDF.

cles undergo little digestion until they are reduced in size (Wilson and Hatfield, 1997). Different changes in proportions of iNDF and pdNDF between intake and the ruminal pool were observed for small and large particles. For both diets, the proportion of iNDF in total $\mathrm{NDF}$ in small particles $(<2.36 \mathrm{~mm})$ increased between intake (54.5 and $55.4 \%$ of NDF for LF and HF, respectively) and ruminal pool (60.9 and $62.8 \%$ of NDF for $\mathrm{LF}$ and HF, respectively). This was expected, because some pdNDF was digested in these small particles and iNDF was not. However, the proportion of iNDF in large particles $(\geq 2.36 \mathrm{~mm})$ was similar for intake (44.1 and $45.7 \%$ of NDF for LF and HF, respectively) compared with the ruminal pool (44.6 and $44.8 \%$ of NDF for LF and $\mathrm{HF}$, respectively). That is, it appears that pdNDF disappeared from small particles, but not from large particles, in the rumen. Two potential explanations exist for this occurrence. The first is that particles $\geq 2.36$ $\mathrm{mm}$ were heterogeneous and the high-iNDF particles broke down more quickly than the high-pdNDF particles, possibly because of greater fragility caused by increased lignification (McLeod and Minson, 1988). The second possible explanation is that the digestion rate of pdNDF in particles $\geq 2.36 \mathrm{~mm}$ was very low, even negligible. The digestion rate of pdNDF in small and large particles could not be calculated, because pdNDF can disappear from the pools by digestion as well as by passage or particle size reduction. Larger forage particles may indeed undergo negligible NDF digestion because of the small surface area available for bacterial digestion relative to the cell wall volume of the particle (Wilson and Hatfield, 1997). The similar proportions of iNDF in feed and rumen particles $\geq 2.36 \mathrm{~mm}$ suggest that little NDF digestion takes place in particles until they are broken down (by chewing) to $<2.36 \mathrm{~mm}$. Both explanations emphasize the heterogeneity of ruminal pools of particles and fractions.

Rates of passage of particles of various sizes and rates of particle size reduction are seldom reported for highproducing dairy cows, and to our knowledge, this experiment was the first to use this particular method. Fractional passage rates of iNDF in particles $<2.36 \mathrm{~mm}$ and in particles $\geq 2.36 \mathrm{~mm}$ were greater on $\mathrm{LF}$ than on $\mathrm{HF}$ ( $P<0.03, P=0.01$, respectively), and means ranged from $2.10 \% / \mathrm{h}$ (particles $\geq 2.36 \mathrm{~mm}$ on $\mathrm{HF}$ ) to $6.09 \% / \mathrm{h}$ (particles $<2.36 \mathrm{~mm}$ on $\mathrm{LF}$ ), spanning the passage rates observed for total iNDF, as would be expected. The passage rate of pdNDF tended to be greater on LF than 
HF in particles $<2.36 \mathrm{~mm}(P=0.06)$, but the pdNDF passage rate in particles $\geq 2.36 \mathrm{~mm}$ was similar between treatments $(P \geq 0.75)$ and was numerically much slower than the passage rate of iNDF in particles of similar size (Table 4). The range of passage rates of pdNDF in small and large particles $(0.59$ to $2.34 \% / \mathrm{h})$ also spanned the passage rates observed for total pdNDF. The proportion of duodenal iNDF or pdNDF flux contained in particles $\geq 2.36 \mathrm{~mm}$ was quite small ( 13 to $21 \%$ of total; Table 4). A slightly greater proportion of iNDF was found in large duodenal particles on LF than on $\mathrm{HF}(P=0.03)$, and a greater proportion of pdNDF was found in large duodenal particles on HF than on $\operatorname{LF}(P<0.05)$.

The passage rate of total pdNDF tended to be greater for LF than for HF (Table 3). A period $\times$ treatment interaction existed for the passage rate of total iNDF $(P=0.06)$ and starch $(P<0.01)$, so treatment effects could not be determined. The tendency for a greater passage rate of pdNDF for LF than for HF suggests that the passage rate could not be increased on HF to permit greater DMI in response to a more physically filling, more slowly digested diet. The slower passage rate of pdNDF for HF apparently outweighed both the greater digestion rate of pdNDF and the greater rate of particle size reduction for $\mathrm{HF}$ in determining the physical filling effects of the diet.

As a result of greater DMI, yields of raw and 3.5\% FCM also were greater for LF (Table 3 ). Milk fat concentration was lower for LF $(P=0.04)$, possibly because of a tendency for a faster passage rate of pdNDF for $\mathrm{LF}$ and a change in ruminal fermentation. The faster passage rate of pdNDF on LF might have resulted in a greater escape of rumen biohydrogenation intermediates (Harvatine and Allen, 2006). Some partially biohydrogenated fatty acids may inhibit milk fat synthesis and thus lower milk fat concentration (Bauman and Griinari, 2003).

\section{Effect of pVDMI on Response to the Diet}

Many of the treatment effects observed here have been demonstrated previously; the primary hypothesis for this experiment was that the differences in responses of these parameters to treatment would change with increasing $\mathrm{pVDMI}$, used as an index of nutrient demand. Contrary to the hypothesis, individual responses of DMI, digesta passage rates, and FCMY did not depend on preliminary intake (data not shown). Only the response to treatment of ruminal NDF turnover time depended on pVDMI; as pVDMI increased, NDF turnover time increased more greatly for LF than for HF (Figure 3). This is likely why DMI of cows with the greatest $\mathrm{pVDMI}$ did not respond as positively to the LF diet as expected; a longer ruminal NDF turnover

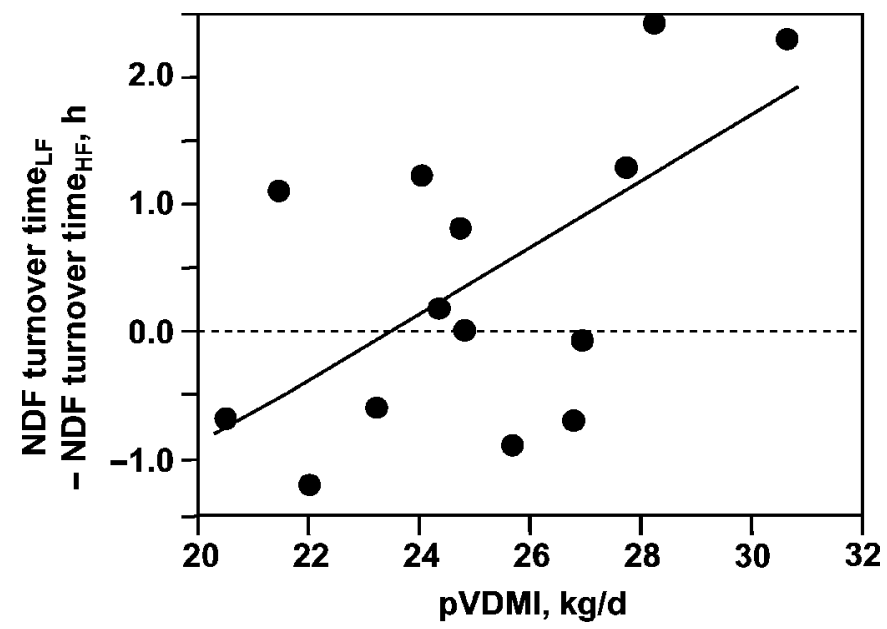

Figure 3. Relationship between mean DMI during the final $4 \mathrm{~d}$ of the preliminary period (pVDMI) and the response to a low-forage $\operatorname{diet}(\mathrm{LF})$ over a high-forage diet (HF) of ruminal NDF turnover time $\left(\mathrm{TOT}_{\mathrm{LF}}-\mathrm{TOT}_{\mathrm{HF}}=-5.6+0.24 \mathrm{pVDMI} ; P=0.05 ; \mathrm{R}^{2}=0.62 ; \mathrm{RMSE}=\right.$ 1.07). Equation is adjusted for sequence.

time suggests that LF may have had more physical filling effects than HF among cows with high pVDMI. Neither digestion rate nor passage rate explains this turnover time effect, because with increasing pVDMI, digestion rate of pdNDF and passage rates of iNDF and pdNDF changed similarly for both diets. Responses of passage rates of iNDF and pdNDF in particles $<2.36$ and $\geq 2.36 \mathrm{~mm}$, and the response of the particle size reduction rate, did not depend on pVDMI (data not shown). It is likely that undetectable interactions between effects of diet and pVDMI on both digestion and passage rates combined to create the detectable NDF turnover time effect.

Inhibition of NDF digestion or passage on LF at high DMI could be caused by direct and indirect effects of increased starch intake and fermentation. Although the DMI response to treatment did not depend on pVDMI, the greater starch concentration in the LF diet still led to a greater increase in starch intake for LF than for HF with increased pVDMI $(P=0.03)$. Greater starch fermentation (resulting from greater starch intake) can inhibit NDF digestion independent of $\mathrm{pH}$ (Grant and Mertens, 1992) and therefore increase NDF turnover time. In addition, the increased titratable acidity of rumen fluid resulting from greater starch fermentation can depress ruminal motility and rumination, thus increasing NDF turnover time (Leek, 2004). Greater starch fermentation can also reduce ruminal $\mathrm{pH}$, thus inhibiting NDF digestion. For both treatments, ruminal $\mathrm{pH}$ tended to decrease as pVDMI increased $(P=0.11)$, and there was no difference in the slopes of the 2 lines 


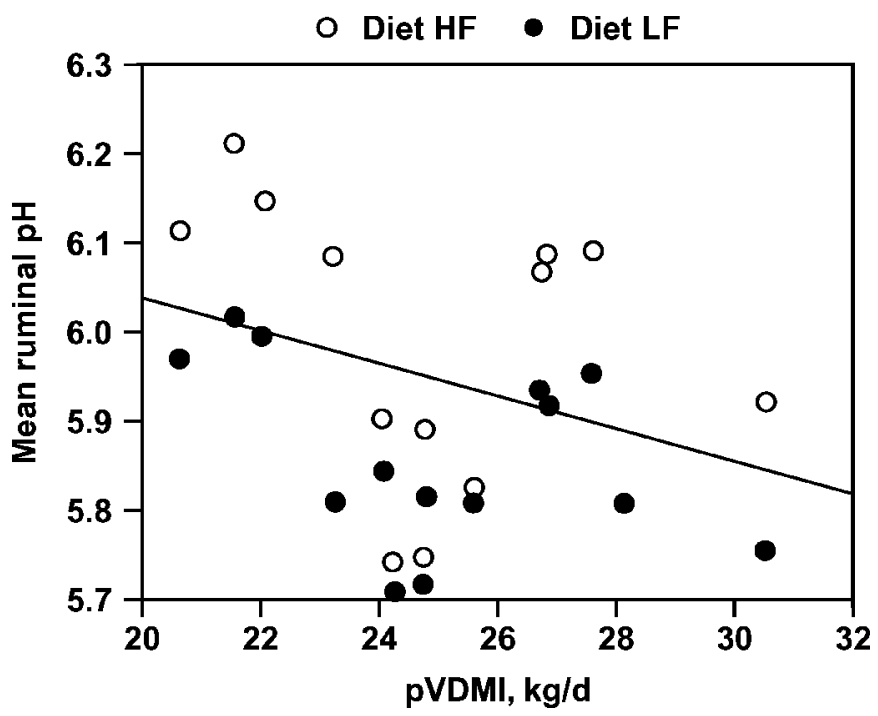

Figure 4. Relationship between mean DMI during the final $4 \mathrm{~d}$ of the preliminary period (pVDMI) and mean daily ruminal $\mathrm{pH}$ (mean of 8 values obtained every $9 \mathrm{~h}$, representing 3 -h intervals in a 24 -h period). Mean $\mathrm{pH}$ was greater for HF than for $\mathrm{LF}(P<0.0001)$, and relative response to treatments did not depend on pVDMI $(P \geq 0.60)$. Across treatments (line depicted), ruminal $\mathrm{pH}=6.3-0.02 \mathrm{pVDMI}$ $\left(P=0.10, \mathrm{R}^{2}=0.16, \mathrm{RMSE}=0.14\right)$. The equation is adjusted for period.

$(P \geq 0.60$; Figure 4). However, mean ruminal $\mathrm{pH}$ was lower for LF than for HF $(P<0.0001$; Table 3$)$, so any effect of decreasing $\mathrm{pH}$ with increasing $\mathrm{pVDMI}$ on NDF digestion, rumination, or rumen motility was likely more severe for LF than for HF. Therefore, it is possible that greater starch intake and the resulting production of fermentation acid caused a longer NDF turnover time on LF with increasing pVDMI.

Relationships previously reported in a similar experiment (Voelker et al., 2002) were between response and preliminary milk yield (or milk energy output), but the same relationships also existed with preliminary DMI, so similar responses were expected, but not observed, in the current experiment. The high-forage and lowforage diets in the 2 experiments contained very similar proportions of total NDF (24 and 31\% of dietary DM for both experiments) and starch (33 and $23 \%$ of dietary DM for both experiments). The previous experiment used 32 cows and the present experiment used only 14 cows. However, the ranges of preliminary DMI and FCMY were similar for the 2 sample groups, and a 12 animal subgroup of ruminally cannulated cows in the 32-cow study detected dependencies of DMI and ruminal kinetic responses on pVDMI. However, several differences exist between the 2 experiments that might have contributed to the observation of different responses.

The largest difference between the 2 experiments was the expected fermentation characteristics of starch in the diets. The greater fermentation rate and ruminal digestibility of starch in the rolled high-moisture corn used in the previous experiment, compared with ground dry corn used in the current experiment, likely affected DMI. Oba and Allen (2003a) reported that increasing dietary starch concentration increased DMI when grain was more slowly fermented (dry corn), but not when it was more rapidly fermented (high-moisture corn). It is likely that digesta in the previous experiment were more rapidly fermented or escaped more quickly from the rumen compared with digesta in the present experiment, or both. This might have caused cows with lower pVDMI in the previous experiment to respond more negatively to the low-forage diet, which would contribute to an increasingly positive response to that diet as pVDMI increased. Although diet starch fermentability likely was a primary contributor to the different responses in the 2 experiments, other differences also might have contributed to those responses. These differences include greater dietary concentration of forage NDF (but not total NDF) in the previous experiment, compared with the current experiment, and the inclusion of nonforage fiber sources and a fat supplement in the previous experiment only. Differences also might have included variables such as forage NDF digestibility and dietary particle size distributions, which were not measured in the previous experiment.

\section{CONCLUSIONS}

A longer NDF turnover time on LF with increasing pVDMI led to responses of DMI and milk production to $\mathrm{HF}$ and LF diets that were independent of pVDMI. This response might have been mediated by diet effects on NDF turnover time. The results of this experiment suggest that models that predict intake need to account not only for the effects of nutrient demand, but also for the effects of the interactions of feed fractions (such as starch and NDF) on the intake responses of individual cows to high-forage and low-forage diets.

\section{ACKNOWLEDGMENTS}

The authors thank D. G. Main, R. A. Longuski, Y. Ying, C. S. Mooney, B. J. Bradford, R. E. Kreft, and the staff of the Michigan State University Dairy Cattle Teaching and Research Center for their technical assistance, and West Central Soy for donation of the SoyPlus protein supplement.

\section{REFERENCES}

Allen, M. S. 1996. Physical constraints on voluntary intake of forages by ruminants. J. Anim. Sci. 74:3063-3075.

Allen, M. S. 2000. Effects of diet on short-term regulation of feed intake by lactating dairy cattle. J. Dairy Sci. 83:1598-1624. 
AOAC. 1990. Official Methods of Analysis. 15th ed. Vol. 2. Assoc. Off. Anal. Chem., Arlington, VA.

Balch, C. C., and A. Kelly. 1951. Factors affecting the utilization of food by dairy cows. 3. Specific gravity of digesta from the reticulorumen of cows. Br. J. Nutr. 4:395-398.

Bauman, D. E., and J. M. Griinari. 2003. Nutritional regulation of milk fat synthesis. Annu. Rev. Nutr. 23:203-227.

Bradford, B. J., and M. S. Allen. 2004. Milk fat responses to a change in diet fermentability vary by production level in dairy cattle. J. Dairy Sci. 87:3800-3807.

Broderick, G. A., and J. H. Kang. 1980. Automated simultaneous determination of ammonia and total amino acids in rumen fluid and in vitro media. J. Dairy Sci. 63:64-75.

Burato, G. M., J. A. Voelker, and M. S. Allen. 2001. Effects of pretrial milk yield on feed intake, production, and feeding behavior responses to forage particle size by lactating cows. J. Dairy Sci. 84(Suppl. 1):199. (Abstr.)

Campling, R. C., M. Freer, and C. C. Balch. 1961. Factors affecting the voluntary intake of food by cows. 2 . The relationship of digesta in the reticulo-rumen and the rate of disappearance of digesta from the alimentary tract. Br. J. Nutr. 15:531-540.

Chai, K., P. M. Kennedy, and L. P. Milligan. 1984. Reduction in particle size during rumination in cattle. Can. J. Anim. Sci. 64(Suppl.):339. (Abstr.)

Cochran, R. C., D. C. Adams, J. D. Wallace, and M. L. Galyean. 1986. Predicting digestibility of different diets with internal markers: Evaluation of four potential markers. J. Anim. Sci. 63:1476-1483.

Dado, R. G., and M. S. Allen. 1995. Intake limitations, feeding behavior, and rumen function of cows challenged with rumen fill from dietary fiber or inert bulk. J. Dairy Sci. 78:118-133.

Goering, H. H., and P. J. Van Soest. 1970. Forage Fiber Analysis (Apparatus, Reagents, Procedures, and Some Applications). Agric. Handbook No. 379. Agric. Res. Serv.-USDA, Washington, DC.

Grant, R. J., and D. R. Mertens. 1992. Influence of buffer $\mathrm{pH}$ and raw corn starch addition on in vitro fiber digestion kinetics. J. Dairy Sci. 75:2762-2768.

Hach, C. C., B. K. Bowden, A. B. Lopelove, and S. V. Brayton. 1987. More powerful peroxide Kjeldahl digestion method. J. AOAC 70:783-787.

Harvatine, K. J., and M. S. Allen. 2005. The effect of production level on feed intake, milk yield, and endocrine responses to two fatty acid supplements in lactating cows. J. Dairy Sci. 88:4018-4027.

Harvatine, K. J., and M. S. Allen. 2006. Fat supplements affect fractional rates of ruminal fatty acid biohydrogenation and passage in dairy cows. J. Nutr. 136:677-685.

Hoover, W. H. 1986. Chemical factors involved in ruminal fiber digestion. J. Dairy Sci. 69:2755-2766.

Karkalas, J. 1985. An improved enzymatic method for the determination of native and modified starch. J. Sci. Food Agric. 36:10191027.

Leek, B. F. 2004. Digestion in the ruminant stomach. Pages 438-474 in Dukes' Physiology of Domestic Animals. 12th ed. W. O. Reece, ed. Cornell Univ. Press, Ithaca, NY.

Lehman, F. 1941. Die lehre vom ballast. Z. Tierphysiol. Tierernaehr. Futtermittelkd. 5:155-173.

McLeod, M. N., and D. J. Minson. 1988. Large particle breakdown by cattle eating ryegrass and alfalfa. J. Anim. Sci. 66:992-999.
Mertens, D. R. 1994. Regulation of forage intake. Pages 450-493 in Forage Quality, Evaluation, and Utilization. G. C. Fahey Jr., M. Colins, D. R. Mertens, and L. E. Moser, ed. Am. Soc. Agron., Crop Sci. Soc. Am., and Soil Sci. Soc. Am., Madison, WI.

NRC. 2001. Nutrient Requirements of Dairy Cattle. 7th rev. ed. Natl. Acad. Press, Washington, DC.

Oba, M., and M. S. Allen. 1999a. Effects of brown midrib 3 mutation in corn silage on dry matter intake and productivity of high yielding dairy cows. J. Dairy Sci. 82:135-142.

Oba, M., and M. S. Allen. 1999b. Evaluation of the importance of the digestibility of neutral detergent fiber from forage: Effects on dry matter intake and milk yield of dairy cows. J. Dairy Sci. 82:589-596.

Oba, M., and M. S. Allen. 2003a. Effects of corn grain conservation method on feeding behavior and productivity of lactating dairy cows at two dietary starch concentrations. J. Dairy Sci. 86:174-183.

Oba, M., and M. S. Allen. 2003b. Effects of corn grain conservation method on ruminal digestion kinetics for lactating dairy cows at two dietary starch concentrations. J. Dairy Sci. 86:184-194.

Okine, E. K., and G. W. Mathison. 1991. Reticular contraction attributes and passage of digesta from the ruminoreticulum in cattle fed roughage diets. J. Anim. Sci. 69:2177-2186.

Poppi, D. P., B. W. Norton, D. J. Minson, and R. E. Hendricksen. 1980. The validity of the critical size theory for particles leaving the rumen. J. Agric. Sci. 94:275-280.

Sheperd, A. C., and D. K. Combs. 1998. Long-term effects of acetate and propionate on voluntary feed intake by midlactation cows. J. Dairy Sci. 81:2240-2250.

Tyrrell, H. F., and J. T. Reid. 1965. Prediction of the energy value of cow's milk. J. Dairy Sci. 48:1215-1233.

Van Soest, P. J., J. B. Robertson, and B. A. Lewis. 1991. Methods for dietary fiber, neutral detergent fiber, and nonstarch polysaccharides in relation to animal nutrition. J. Dairy Sci. 74:35833597.

Voelker, J. A., and M. S. Allen. 2003. Pelleted beet pulp substituted for high-moisture corn: 3. Efffects on rumen fermentation, $\mathrm{pH}$, and microbial protein efficiency in lactating dairy cows. J. Dairy Sci. 86:3562-3570.

Voelker, J. A., G. M. Burato, and M. S. Allen. 2002. Effects of pretrial milk yield on responses of feed intake, digestion, and production to dietary forage concentration. J. Dairy Sci. 85:2650-2661.

Wildman, E. E., G. M. Jones, P. E. Wagner, R. L. Boman, H. F. Troutt Jr., and T. N. Lesch. 1982. A dairy cow body condition scoring system and its relationship to selected production characteristics. J. Dairy Sci. 65:495-501.

Wilson, J. R., and R. D. Hatfield. 1997. Structural and chemical changes of cell wall types during stem development: Consequences for fibre degradation by rumen microflora. Aust. J. Agric. Res. 48:165-180.

Wilson, J. R., and P. M. Kennedy. 1996. Plant and animal constraints to voluntary feed intake associated with fibre characteristics and particle breakdown and passage in ruminants. Aust. J. Agric. Res. 47:199-225.

Zinn, R. A., and F. N. Owens. 1986. A rapid procedure for purine measurement and its use for estimating net ruminal protein synthesis. Can. J. Anim. Sci. 66:157-166. 